\author{
Kateryna Melnychuk \\ (Institute of History of Ukraine, National Academy of Sciences of Ukraine) \\ https://orcid.org/0000-0002-4732-6695 \\ E-mail: katerynamelnychuk92@gmail.com
}

\title{
The Polish and Jewish People in the Work of Peasant Self-Government in the Right-Bank Ukraine in the Second Half of the 19th and the Beginning of the 20th Centuries
}

\author{
Udział Polaków i Żydów w pracy organów samorzqdu wiejskiego \\ na Prawobrzeżnej Ukrainie w drugiej połowie XIX - poczq̨tku XX wieku
}

\section{ABSTRACT}

The abolition of serfdom in 1861 was the beginning of global reformations that dealt with the administrative and territorial division of the empire. According to the new division, the lowest territorial unit was a rural community (territorial community) in Kyiv, Podolia and Volhynia guberniyas, the highest - volost. The control of rural communities was performed by peasant self-government - volost and rural government which were formed and provided by peasants (members of the community). However, excepting community affairs, the legislator charged the peasant self-government to execute a number of urgent functions in the government (fiscal, legal, police, static and educative functions). For that reason, the peasant authorities were degraded to the position of the lowest link in the hierarchy of the government. The peasant self-government was restricted by the

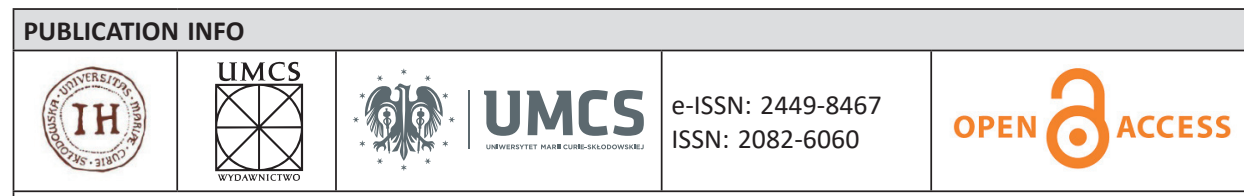

THE AUTHOR'S ADDRESS: Kateryna Melnychuk, the Institute of History of Ukraine of the National Academy of Sciences of Ukraine Institute of History of Ukraine, 4 Mykhailo Hrushevskyi Street, Kyiv 01001, Ukraine

SOURCE OF FUNDING: Statutory Research the Institute of History of Ukraine of the National Academy of Sciences of Ukraine Institute of History of Ukraine

\begin{tabular}{|l|l|l|l|}
\hline $\begin{array}{l}\text { SUBMITTED: } \\
2020.07 .25\end{array}$ & $\begin{array}{l}\text { ACCEPTED: } \\
2021.01 .18\end{array}$ & $\begin{array}{l}\text { PUBLISHED ONLINE: } \\
2021.06 .30\end{array}$ & CC \\
\hline $\begin{array}{l}\text { WEBSITE OF THE JOURNAL: } \\
\text { https://journals.umcs.pl/rh }\end{array}$ & $\begin{array}{l}\text { EDITORIAL } \\
\text { COMMITTEE E-mail: } \\
\text { reshistorica@umcs.pl }\end{array}$ & Crossref dol \\
\hline
\end{tabular}


resolutions and circulars of Ministry of Interior, general-governor, general, governor in peasant affairs and "myrovyi poserednyk". As a matter of fact, the talent acquisition to the peasant self-government office was implemented with a number of restrictions established by the "Regulation on the peasants withdrawal from serfdom" in 1861.

The specific characteristic of the right-bank Ukraine was the diversity of area, after the Ukrainians the second most populated were the Jewish people, the third - Polish. An impressive part of Polish and Jewish nationalities lived in peasant community so that there was a problem of their participation in the work of peasant self-government. Avoiding putting "chuzhynziv" (people who were not the members of peasant community) in the main positions of rural administration, the restrictions were implemented on the spot. Still, the position of clerk (pisar) was accessible for those wishing to work in volost or rural government. The article deals with the problem of human resourcing and the presence of Polish and Jewish nationalities in the peasant self-government in the South-Western region ${ }^{1}$ of the Russian Empire in the second half of the 19th - the beginning of the 20th centuries. The way of rotating workers in the rural administration, their level of education, professional achievements, employment and remuneration terms are emphasized in the article. Moreover, certain cases of working Jewish and Polish as clerks in rural administrations are described.

Key words: peasant self-government, volost, rural community, the right-bank Ukraine, South-Western region, the Polish and Jewish people, myrovyi poserednyk, governor

\section{STRESZCZENIE}

Zniesienie pańszczyzny w 1861 r. było początkiem globalnych przemian, dotyczących podziału administracyjnego imperium. Zgodnie z nowym podziałem $\mathrm{w}$ województwach kijowskim, podolskim i wołyńskim najniższą jednostką terytorialną była "gmina wiejska" (hromada terytorialna), najwyższą - włość. Zarządzaniem gminami wiejskimi zajmowały się organy samorządu wiejskiego - zarząd włości i wsi, które tworzyli i zapewniali ich działalność chłopi (członkowie hromady). Jednak oprócz spraw hromady, ustawodawca zobowiązał samorząd wiejski do pełnienia szeregu funkcji niezbędnych $\mathrm{w}$ zarządzaniu publicznym (skarbowa, prawna, policyjna, statystyczna, oświatowa). Więc, administracje chłopskie zostały faktycznie najniższym ogniwem w hierarchii zarządzania publicznego. Samodzielność samorządu wiejskiego ograniczały uchwały i okólniki Ministerstwa Spraw Wewnętrznych, Generał-gubernatora, gubernatora, komisarze prowincjonalni ds. obecności oraz mediatora. Nawet dobór kadr dla instytucji samorządu wiejskiego odbywał się z uwzględnieniem szeregu ograniczeń przewidzianych w „Przepisach o uwolnieniu chłopów od pańszczyzny" z 1861 r.

Cechą szczególną Ukrainy Prawobrzeżnej było zróżnicowanie narodowe regionu, na drugim miejscu po Ukraińcach byli Żydzi, na trzecim Polacy. Znaczna część przedstawicieli narodowości polskiej i żydowskiej żyła w środowisku chłopskim, więc pojawił się problem ich udziału w działalności samorządu wiejskiego. Aby uniemożliwić „obcym” (nie członkom hromady, osobom innej wiary) zajmowanie ważnych stanowisk w administracjach wiejskich, wprowadzano lokalne ograniczenia. Jednak stanowisko pisarza urzędowego pozostawało stosunkowo dostępne dla osób pragnących pracować we włości lub w zarządzie wsi.

1 South-Western region (South-Western Krai) - in the Russian Empire in the 19th and the beginning of the 20th centuries, the part of Western region, the common name for three guberniyas (Kyiv, Podolia and Volhynia). 
Proponowane badanie dotyczy problemu obsady kadrowej i obecności przedstawicieli narodowości polskiej i żydowskiej w samorządach wiejskich w południowo-zachodnim regionie Cesarstwa Rosyjskiego w drugiej połowie XIX i na początku XX w. Scharakteryzowano kolejność rotacji pracowników administracji wiejskich, ich wykształcenie, poziom profesjonalizmu, warunki pracy i płacy. Opisano niektóre przypadki służby Żydów i Polaków w charakterze pisarzy urzędowych w administracjach wiejskich.

Słowa kluczowe: samorządy wiejskie, gmina, gromada wiejska, społeczność chłopska, prawobrzeżna Ukraina, Kraj Południowo-Zachodni

\section{INTRODUCTION}

With the introduction of the "Regulation on the peasants withdrawal from serfdom" in 1861, changes were introduced to the administrative and territorial division which primarily related to peasants. Additionally, the system of government undergone a transformation, the government gave peasants the right to be autonomous in the economic and administrative matters. The formation and upkeep of rural administrative units were put in the hands of the communities so that the government was relieved of supporting them. Meanwhile, the governance was concerned about the possibility of losing control over the village - the main tax resource. In order to prevent potential disobedience of peasants, the legislator approved rather weird construction of "peasant self-government", principles of which were involved restricting the "self-government". Due to that the rural communities were not autonomous at the stage of acquisition. The purpose of this article is to analyze the problem of participation of Polish and Jewish nationalities in peasant self-governments in the South-Western region in the second half of the 19th - the beginning of the 20th centuries.

\section{HISTORIOGRAPHY REVIEW}

The introduction and functioning of peasant self-government are of interest to the society of per-revolutionary Russia. In particular, the subject of discussion encompassed regulations concerning the creation of a new administrative division, the introduction of peasant community and volost. K. Aksakov declared against excessive interference of state authority in the election of members of peasant self-government ${ }^{2}$.

2 К. Аксаков, Замечание на новое административное устройство крестьян в России, Лейпциг 1861, s. 76-77. 
The poet and publicist M. Ogarev sai bout non-independent of peasant self-government ${ }^{3}$. Such researchers as S. Latyshev and A. Yanovskyi, in their texts published in the „Encyclopedic dictionaries of Brockhaus and Efron" analyzed the legal terms of volost and rural government, as well as the scope of their cooperation with the governance ${ }^{4}$. However, the participation of the Polish and Jewish people hasn't become so far the main subject of the research. After January Uprising in 1863, anti-Polish rhetoric was spread in press which existed during the second half of the 19th century. In particular, „Vestnik of Yugo-Zapadnoi i Zapadnoi Rossii” press published articles of chauvinistic content, characterizing negative impact of the Polish on the formation of peasant self-governments ${ }^{5}$.

The Soviet historiography studied the activity of rural administrative units without emphasizing their ethnic composition. A feature of the Soviet researches was the definition of "kulak" formation of peasant self-government. In spite of one-sided negative assessment of peasant establishments, as "the organ of peasants oppression and exploitation", the Soviet works provide valuable materials of analytical nature. In this vein, scientist $S$. Bodnarevskyi analyzed the activities of volost establishments, determined the structure of peasant administrations, items of their costs and revenues, wage rates ${ }^{6}$. Researcher D. Poida in his monograph dedicated to peasant struggle for its land in the right-bank Ukraine, analyzed the population of this region. The scholar also studied the Polish presence among various classes which made it possible to notice the Polish transition from nobility to peasantry ${ }^{7}$.

In modern peasant studies, Ukrainian researches have paid considerable amount of attention to the study of peasant self-government. Thus, the object of study of scientist I. Verkhovtseva were the organs of the aforementioned self-government (1861-1917) of European regions

3 Н. Огарев, Разбор нового крепостного права обнародованого 19 февраля 1861 года в положениях о крестьянах, вішедшых из крепостной зависимости, Аондон 1861, s. 82-83.

4 Сельское общество, w: Эничикопедический словарь, t. 29, Сахар - Сем мудрецов, red. К.К. Арсеньев, Ф.Ф. Петрушевский, Санкт Петербург 1900, s. 377; С. Датышев, Волость, w: Эничилопедический словарь, t. 7, Волапюк - Вьговские, red. К.К. Арсеньев, Ф.Ф. Петрушевский, Санкт Петербург 1892, s. 93-98.

5 Интересний мировой посредник, „Вестник Юго-Западной Росии” 1863, август, s. 202-209; Первый крестьянский праздник, „Вестник Юго-Западной Росии” 1863, Іюдь, s. 102; Из Житомира „Вестник Юго-Западной Росии” 1863, Іюль, s. 104-108.

6 А. Боднаревський, Волосне управління та становище селян на Україні після реформи 1861 року, Київ 1961, s. 72-73.

7 Д. Пойда, Крестьянское движение на Правобережной Украине в пореформенный период (1866-1900 г2.), Днепропетровск 1960, s. 26. 
of the Russian Empire ${ }^{8}$. The researcher analyzed the processes of rotation in peasant administrations and noted the lowest level of education of their workers ${ }^{9}$. Thesis work of historian A. Kasian devoted to volost ruling in the right-bank Ukraine in the second half of the 19th century, touches upon a question of Polish presence in the organs of peasant selfgovernment. However, we consider A. Kasian's statement about „nonUkrainian" nature of volost ruling on the right-bank to be exaggerated ${ }^{10}$. The works of researcher Yu. Zemskyi are devoted to the problem of Polish factor in the right-bank Ukraine ${ }^{11}$. In one of monographs, the scholar studied the role of Polish declassed nobility in the society of the South-Western region, and pointed to its social and partly cultural assimilation with Ukrainian peasantry ${ }^{12}$. A thorough analysis of the situation of declassed nobility was made by French scientist D. Beauvois in his study about the struggle of Polish elite for the influence in the South-Western region in the second half of the 19th century ${ }^{13}$. Russian researcher L. Horizontov described the main stages of struggle between Russian statehood and Polish historical tradition in the 19th century. He touched upon the issue of removing Polish from public service in the Russian Empire ${ }^{14}$.

\section{THE DISPLACEMENT OF POLISH FROM PRIVILEGED STATUS, THEIR SOCIO-ECONOMIC POSITION}

The socio-political situation in the Russian Empire changed for the worse hrough for the inhabitants of Polish nationality in the second half of the 19th century. Discrimination policy against the Polish people,

8 I. Верховцева, Між корпоративністю і бюрократизмом: самоврядування селян у Російській імперії (друга половина XIX - початок XX ст.), Черкаси 2018, s. 9.

9 Ibidem, s. 167-177.

10 А. Касян, Волосне управління на Правобережній Украйні (1861-1917 рр.), Черкаси 2017, s. 102.

11 Ю. Земський, Особливості генези польського націоналізму в Правобережній Україні середини ХIX ст., „Гуманітарний Журнал” 2009, 3-4; idem, Еволюиія польсько-російських взаємин в Правобережній Україні в контексті націоналізацій свідомості в Російській імnерії середини XIX cm., „Наукові Записки Національного Університету. Острозька Академія. Серія Історичні науки" 2011, 17, s. 116-126.

12 Ю. Земський, Польська, російська та украӥнська еліти в змаганнях за Правобережну Україну середини ХІХ століття, Хмельницький 2011, s. 114.

13 Д. Бовуа, Гордиев узел Российской илперии: Власть, иляхта и народ на Правобережной Украине (1793-1914), Москва 2011, s. 705, 711, 720, 727.

14 П.Е. Горизонтов, Парадоксы имперской политики: поляки в России и русские в Польше, Москва 1999, s. 45, 64. 
introduced by Nicholas I, continued to manifest itself during the 19th century and was not abolished even during the World War I. Thus, the representatives of Polish nationality were removed from leading duties on the public service, restricted access to higher educational establishments ${ }^{15}$. In the second half of the 19th century, the situation of the Polish people in the Empire was complicated by the reaction of the governance to Polish rebellion in 1863 that reflected on the right-bank Ukraine. The rebellion in Kyiv, Podolia and Volhynia guberniyas was evident through the formation of armed groups, conflicts with police and military ${ }^{16}$. The sympathy of local nobility for rebels was also expressed by means of peaceful actions - women were wearing mourning clothes and set a memorial service for those killed in January rebellion ${ }^{17}$. All this led to the appropriate steps of starting the rebellion - reducing the number of the nobles, restrictions on possessing the land, removing from public duties. Thus, in the decree of December 10, 1865, the Polish people were forbidden to buy land in nine western guberniyas, including guberniyas in the South-Western region ${ }^{18}$. In the decree of July 4, 1863, it was no longer possible to recognize cases of noble Polish birth ${ }^{19}$, so those who did not prove their aristocratic status became taxable (peasants or bourgeois). "Chynshovyky" ${ }^{20}$ were also enlisted to the peasantry, among which 13,200 were ethnic Polish ${ }^{21}$. They mostly lived on the landlord's leasehold and did not have the possibility to buy allotment. Peasant communities were unwillingly admitted to "chynshovyky" and due to lack of communal ownership of land in Kyiv, Podolia and Volhynia guberniyas, new members of the community were not provided with land ${ }^{22}$.

\footnotetext{
15 Ibidem, s. 45.

16 Державний Архів Хмельницької Області [dalej: ДАХмО], fond [dalej: f.] 73, opys [dalej: op.] 1, sprava [dalej: spr.] 6, s. 48; Державний Архів Житомирської Області [dalej: ДАЖО], f. 497, op. 1, spr. 8, s. 6.

17 Державний Архів Вінницької Області [hereinafter: ДАВiО], f. 200, op. 1, spr. 313, s. 7.

18 Полное Собрание Законов Российской Империи [daleј: ПСЗРИ], собрание второе, t. 40, отделение второе, 1865, Санкт Петербург 1867, nr 42759, s. 326-327.

19 ПСЗРИ, собрание второе, t. 38, отделение первое, 1863, Санкт Петербург 1866, nr 39825, s. 757.

20 "Chynshovyky" - is a category of rural population (personally free) that paid money tax for the use of state land or private lander - „chynsh". See in detail in: А. Гурбик, Чиншові селяни, w: Енцииклопедія історії Украӥни, t. 10, T-Я, red. В.А. Смолій еt al., Київ 2013, s. 553.

21 In 1870s the total number of "chynshovyky" in the right-bank Ukraine was 266984 people. See in detail in: Д. Бовуа op. cit., s. 727 . There were 132511 people of Catholics and 13200 of ethnic Polish among ",chynshovyky”. See in detail in: Д. Пойда, op. cit., s. 26.

22 ДАЖО, f. 498, op. 1, spr. 71, s. 172.
} 
From the mid-1860s to the beginning of the 20th century the number of the Polish in peasantry grew almost twice. So, in 1860s-70s there were 92,026 ethnic Polish among all peasants (including "chynshovyky"), and there were 156,086 people in the beginning of the 20th century. The total number of Polish in Kyiv, Podolia and Volhynia guberniyas as well as their part in peasantry and administrative structures are presented in Table 1.

Table 1. Polish population and its representation in peasantry and administrative structures in the right-bank Ukraine in the beginning of the 20th century ${ }^{23}$.

\begin{tabular}{|l|c|c|c|c|c|c|c|c|}
\hline & \multicolumn{2}{|c|}{$\begin{array}{c}\text { Volhynia } \\
\text { guberniya }\end{array}$} & \multicolumn{2}{c|}{$\begin{array}{c}\text { Podolia } \\
\text { guberniya }\end{array}$} & \multicolumn{2}{c|}{ Kyiv guberniya } & \multicolumn{2}{|c|}{ Total } \\
\hline & $\begin{array}{c}\text { Number } \\
\text { of people }\end{array}$ & $\%$ & $\begin{array}{c}\text { Number } \\
\text { of people }\end{array}$ & $\%$ & $\begin{array}{c}\text { Number } \\
\text { of people }\end{array}$ & $\%$ & $\begin{array}{c}\text { Number } \\
\text { of people }\end{array}$ & $\%$ \\
\hline $\begin{array}{l}\text { Residents } \\
\text { of Polish } \\
\text { nationality }\end{array}$ & 184,161 & $6,16 \%$ & 69,156 & $2,27 \%$ & 68,791 & $1,93 \%$ & 322,108 & $\begin{array}{c}4.5 \% \text { of all } \\
\text { population of } \\
\text { the region }\end{array}$ \\
\hline $\begin{array}{l}\text { Polish of } \\
\text { peasantry }\end{array}$ & 102,540 & $55,68 \%$ & 31,327 & $45,3 \%$ & 22,219 & $32,3 \%$ & 156,086 & $\begin{array}{c}48,46 \% \text { of peas- } \\
\text { ants of Polish } \\
\text { nationality }\end{array}$ \\
\hline $\begin{array}{l}\text { Workers of } \\
\text { admin. }\end{array}$ & 346 & $0,18 \%$ & 205 & $0,30 \%$ & 173 & $0,25 \%$ & 724 & $\begin{array}{c}\text { 0,22\% of peas- } \\
\text { ants of Polish } \\
\text { nationality }\end{array}$ \\
\hline
\end{tabular}

So, in the second half of the 19th century, the Polish people faced the problem of preserving noble privileges in the South-Western region. Unwillingness to go down social ladder brought Polish to the presence of "free professions" like advocacy, medicine, pharmacy and merchants ${ }^{24}$. But, not all declassed nobility had the opportunity to get proper education and start their own business, so for most military service seemed to be a good option ${ }^{25}$. Some representatives of Polish nationality worked in the administrative structures, mainly office workers. Thus, the establishments of peasant self-government, volost governance and peasant government became one of the options to obtain the means of subsistence for the intelligent category of Polish population.

23 The table is made by researchers calculating В. Палієнко, Місия історичного розселення польської людності в кінці ХІХ - початок ХХ ст., Київ 1998, s. 6-22; Д. Пойда, ор. cit., s. 25-26; Д. Бовуа, op. cit., s. 652.

24 Л.Е. Горизонтов, ор. cit., p. 64.

25 Ibidem, s. 45. 


\section{THE STRUCTURE OF PEASANT SELF-GOVERNMENT}

Peasant self-government was introduced by the "Regulation on the peasants withdrawal from serfdom" in 1861 and extended to all categories of peasants (former serfs, state peasants). According to the administrative division, the lowest territorial unit was rural community ${ }^{26}$ which was the part of the highest administrative unit - volost ${ }^{27}$. That's why, peasant self-government took place on two levels - of a volost and of a rural community. A volost government was carried out by three levels of authority: volost assembly, court and government. The volost governance was the executive branch of peasant self-government in volost, which was formed of an elder (starshina), his assistant, tax collector and all chiefs of villages (village starost) ${ }^{28}$. All candidates mentioned above were elected through volost peasants who owned land, farm, and permanently lived within volost, not younger than 25 years old, of no criminal background. The election of candidates took place once every three years, except for a tax collector (annually). Re-election of servants was not prohibited on the assumption of their agreement. The candidate could resign from the position offered by the community only in three cases: 1 . if he was over 60 years old; 2 . if he had served three-year term; 3 . if he was poor health ${ }^{29}$. Hired workers, such as keepers, public watchers (churchwarden, head of grain warehouse, etc.), clerks were appointed by the chiefs of administrations ${ }^{30}$.

The rural community was managed by rural gathering and rural government which consisted of a starost, a tax collector and workers: a village clerk, keepers and public watchers of public structures ${ }^{31}$. Volost government was headed by a volost elder, the rural one was headed by a starost. These candidates were approved by state servants and such a leader for the peasant administration in the South-Western region

26 "Rural community” is an administrative and economic union, consisted of one or more villages, small villages. See in detail in: Федорова Н., Сельское общество, w: Петр Аркадьевич Стольпин: Энцииклопедия, red. В.В. Шелохаев, Москва 2011, s. 399-403.

27 Volost is an administrative and territorial unit that included rural communities, numbered from 300 to 2000 people. However, in the late 19th century, the number of inhabitants in one volost increased to 19000 people. See in detail in: И. Беловинский, Иллюстрированный эницклопедический историко-бытовой словарь русского народа, Москва 2007, s. 102.

28 ПСЗРИ, собрание второе, t. 36, отделение первое, 1861, Санкт Петербург 1863, nr 36657, s. 154 (Стаття 87).

29 Ibidem, s. 158.

30 Ibidem.

31 Ibidem, s. 147. 
was a „myrovyi poserednyk" 32 . The main responsibilities of „myrovyi poserednyk" were: to control over introduction and activities of peasant self-government, to remove or approve servants elected to the peasant government, to give permission to run volost meetings, to considerate all complaints against peasant servants. So, a peasant self-government was formed through elections of rural community members but was under the control of state government.

\section{THE ROLE OF VOLOST CLERK (PISAR) IN THE STRUCTURE OF PEASANT SELF-GOVERNMENT}

A clerk was important figure in peasant self-government. He dealt with paperwork of the structure: he registered the orders of volost elders, verdicts of volost gatherings and volost court, made lists of family, reserve and retired military ranks, warriors, military cavalry. He also recorded tax collection in his tax notebook, income and expenditure books ${ }^{33}$. Also, volost structures participated in supporting volost educational and medical institutions and kept relevant documents, which were designed by the clerk $^{34}$. It was possible to obtain sales and purchase agreements, obtain a property in volost government, appropriate books were kept with the recording of witnessed documents ${ }^{35}$. N. Astyrev aptly pointed out that, in fact, a clerk conducted all cases directly related to six ministries: the ministry of internal affairs, finance, military, justice, education and state property $^{36}$. The clerk was personally responsible for the authenticity of paperwork of rural structures and in case of violation, he was punished with fine, dismissal or arrest ${ }^{37}$. The clerk, as an employee, reported to an elder or starost, but in fact he became the head of those structures where the elected servants were illiterate. The illiteracy of heads of peasant administrations was the problem of imperial scale, so there was $41 \%$

32 „Myrovyj poserednyk" - government man in the Russian Empire who took charge of peasant governance. See in detail in: A.Я., Мировые посредники, w: Энцииклопедический словарь, t. 19, Мекенен - Мифу-Баня, red. К.К. Арсеньев, Ф.Ф. Петрушевский, Санкт Петербург 1896, s. 424.

33 ПСЗРИ, t. 36, nr 36657, s. 155.

34 ДАХмО, f. 75, op. 1, spr. 24, s. 35.

35 ДАХмО, f. 72, ор. 1, spr. 62, s. 24.

36 Н. Астырев, В волостных писарях. Очерки крестьянского самоуправления, Москва 1886.

37 Центральний Державний Історичний Архів України м. Київ [dalej: ЦДІАК], f. 442 , op. 186 , spr. 271 , s. 16 . 
of illiterate volost foremen and $81 \%$ of illiterate rural heads in $1880^{38}$. Instead of signature rural servants put a seal with applicable prints ",volost elder", „rural starost”, „,volost court"39. However, the possession of seals did not guarantee the power in the hands of rural leaders. We meet many cases became with the participation of volost clerks in various scams, where "wise" servants skillfully forged for their own gain. For instance, in 1905, Tereshchenko, a clerk of Mliiv volost of Cherkasy uyezd of Kiyv guberniya, wrote down the decision contrary to the volost court decision and gave it to the judges for the confirmation with the seal. As the judges could not read, the mistake became known only when it was time to enforce the ordinance ${ }^{40}$. In 1887 the case of Romanovskyi, volost clerk of Skvirskyi division L. Susky was given publicity. Taking advantage of illiteracy of tax collectors, he forged reports, and having found any shortcomings, he forced the collectors to cover from their own funds ${ }^{41}$.

Nevertheless, clerk's work in peasant administrations was not paying a big fortune for an educated and honest person. In the late 19th century, a clerk at a volost governance received 290 rubles per year, an assistant of volost clerk received 30 rubles per, a peasant clerk received 42 rubles per year ${ }^{42}$. The amount of salaries increased and in 1912-1913 clerks received 300 to 600 rubles per year ${ }^{43}$. However, the salary of a clerk in comparison with the employees of guberniya governments (such as an accountant or secretary received 750 rubles per year in the end of the 19th century ${ }^{44}$ ) was lower, moreover, the amount of work and responsibility increased every year.

\section{THE PROBLEM OF JEWISH TENURE IN THE POSITION OF A CLERK (PISAR)}

According to the "General regulation" of 1861, a clerk was assigned by the chiefs of peasant administrations themselves ${ }^{45}$. However, "myrovyi poserednyky" very often intervened and recommended their own

\footnotetext{
38 І. Верховцева, ор. cit., s. 167.

39 Ibidem, s. 177.

40 ЦДІАК, f. 442, op. 704, spr. 199, s. 2.

41 ЦДІАК, f. 442, op. 617, spr. 170, s. 1-7.

42 Based on the data from the journal of Kyiv guberniya in peasant affairs. See in detail in: ЦДІАК, f. 442, op. 701, spr. 383, s. 18-20.

43 С. Боднаревський, оp. cit., s. 72.

44 С. Мещеряков, Уровень материального положения чиновников ключевых институтов управления Оренбургского края во второй половине ХІХ - начале XX в., „Известия Самарского Научного Центра Российской Академии Наук” 2014, 16, 3, 2, s. 404.

45 ПСЗРИ, t. 36, nr 36657, s. 158.
} 
candidates. In fact, the direct supervisor of the volost was the "myrovyi poserednyky". He took an oath of faithful service from the volost head, had the authority to punish or remove him from office, or dismiss any employee of the peasant administration ${ }^{46}$. Also a "myrovyi poserednyky" was overseeing the appointment of clerks. The invasion in the work of peasant self-government was not condemned by either the presence of guberniya or the governors of the region, as they were interested in preventing "unreliable" persons from entering peasant structures. The Jewish people were the most politically "unreliable” in the South-Western region. Mostly literate residents of towns and sometimes villages, the Jewish helped peasants in writing the documents they needed. For example, in 1895 Faim Rovinskyi, a teacher of Jewish children in Pavolochki of Skvurckyi uyezd, wrote appeals, letters to the government structures and sometimes complaints against volost and peasant servants for locals of the surrounding villages ${ }^{47}$. A Jew could be hired as a clerk in case of lack of educated candidates among members of peasant community. Thus, in 1901, Jew Khaim Kapitanskyi was a clerk in Mankovskyi volost governance of Uman district of Kyiv guberniya. Volost elder explained that Khaim was assigned temporarily, as volost documentation urgently needed to be put in order because they could not find a candidate for the position of clerk for a long time. By the decision of Kyiv gubernskyi in peasant affairs, Khaim was dismissed from the position of a clerk. It is interesting that in this case volost peasants complained about the service of a Jew in Mankovskyi volost governance, suspecting dishonesty in running fees. The investigation showed that the Jewish clerk made a mistake only in the calculation of land taxation which led to the reduction in the amount of peasant tax. Servants who assumed funds, were tax collectors elected from peasants ${ }^{48}$.

There was no official ban on Jews holding positions in peasant selfgovernment. But, Jews in the service of volost government caused distrust not only among the peasantry. Provincial government was wary of nonChristians serving as clerks, that's why it made allowances in gaps in law. In the "Regulation on the peasants withdrawal from serfdom" it was stated that representatives of non-peasant estates, residents of other communities were allowed to work as clerks and other hired positions on the

\footnotetext{
46 К. Мацузато, Из комиссаров антиполонизма в просветители деревни: мировые посредники на Правобережной Украине (1861-1917 г2.), „Український Гуманітарний Огляд” 2003, 9, s. 75.

47 ЩДІАК, f. 442, op. 615, spr. 194, s. 2.

48 ЦДІАК, f. 442, op. 700, spr. 56, s. 2.
} 
assumption of proper reputation ${ }^{49}$. Therefore, by separate decrees peasant governmental authorities, and sometimes governors, restricted the access of "undesirable" persons to peasant self-government. In particular, in Podolia gurberniya, by personal recommendation of the governor, Jews and even converts to Christianity were not allowed to become clerks ${ }^{50}$. In Kyiv and Volhynia guberniyas, the assignment of clerks took place only with the approval of "myrovyi poserednyk" in the end of 19th century.

\section{SERVICE OF THE POLISH PEOPLE IN PEASANT ADMINISTRATIONS}

Representatives of another nationality, the Polish, applied for the place of volost clerk. Before the reform in 1861, the Polish were observed as of peasant servants in the right-bank Ukraine. According to the revision in 1839, it is known that in Kyiv and Podolia guberniyas most of uyezd and volost authorities who ruled the peasants were Polish ${ }^{51}$. After reforming the peasant government, according to rather chauvinistic publication "Vistnik of South-Western and Western Russia”, the work of peasant self-government in the right-bank Ukraine was usurped by the Polish ${ }^{52}$. However, inspection conducted in 1898 for the presence of Polish and Catholic employees in volost government in Kyiv, Podolia and Volhynia guberniyas showed a small percentage of them. There were 30 volost clerks in Kyiv guberniya (Polish by nationality, but of Orthodox faith), there were 9 clerks of Polish ethnicity in Podolia, who got Orthodoxy, but their wives were Catholic and there were no clerks of Polish origin in Volynia, but 18 of them were married to Polish Catholics ${ }^{53}$. Persons who were threatened with losing their jobs due to ethnic or religious "unreliability" appealed to governor general not to dismiss them, justifying their position in every possible way. The former volost clerk of Radomyshl uyezd, G. Shuliavskyi of Catholic faith asked not to dismiss him from the post of commissioner secretary, as it was his only source of income. Petitioner pointed to his previous work as a clerk in volost government and begged to consider his large family - a wife and five children who were of Orthodox faith ${ }^{54}$. Later, V. Krezhanivskyi, volost clerk from the same uyezd, who was married to a Polish woman, appealed to the

\footnotetext{
ПСЗРИ, t. 36, nr 36657, s. 158.

ЦДІАК, f. 442, op. 693, spr. 368, s. 36.

A.Е. Горизонтов, op. cit., s. 45.

A. Касян, op. cit., s. 101.

ЦДІАК, f. 442, op. 697, spr. 306, s. 6-9.

ШДІАК, f. 442, op. 694, spr. 34, s. 27.
} 
governor general's office to allow him to continue his service. The public servant exonerated himself by saying that he did not live with his wife and did not know anything about her residence ${ }^{55}$. Mostly, appeals to the governor general did not turned out successful for those who were fired.

So, the number of volost clerks with Polish roots or family ties with Polish women in 1898 was not significant, which is 57 people in 562 volost in South-Western region ${ }^{56}$, which was about $10 \%$ and those who were later dismissed. Restrictions of Polish people from service of public posts led to their removal from work in peasant self-government.

\section{CONCLUSIONS}

Peasant self-government formed after the introduction of the „Regulation on the peasants withdrawal from serfdom" in 1861 became the lowest link in the hierarchy of governance. Representatives elected from rural communities were assigned to the peasant administrations. However, the law did not prohibit to hire people from other communities or classes. Jewish and Polish workers were sometimes hired to serve in volost and rural authority. Jewish service was not approved by the peasant community, so cases of hiring the Jewish people to volost government were rather an exception. Recruitment of the Polish to the posts of volost clerks is more common and there are some objective reasons: 1 ) Polish people took the third place in population after Ukrainians and the Jewish on the territory of South-Western region; 2) a significant number of declassed nobles who descended the social ladder were literate; 3 ) level of literacy among peasants in guberniyas of the right-bank Ukraine was quite low in the second half of the 19th century, ranging from 15 to 20 percentage $^{57}$. However, the number of volost clerks of Polish origin was less than $10 \%$ at the end of the 19th century. So, there is no sense to speak about the significant influence of the Polish factor on the work of peasant self-government. Undoubtedly, the low proportion of Polish and Jewish volost and rural structures was a result of imperial policy of removing them from public administration. Not least important were unsatisfied conditions of work related with increasing workload and scanty earnest.

\footnotetext{
55 ЦДІАК, f. 442, op. 697, spr. 306, s. 12.

56 І. Верховцева, оp. cit., s. 313-315.

57 О. Крижанівська, Вплив реформи 1861 р. на освіту селян України (друга половина XIX - початок XX cm.), w: Проблеми історії України XIX - початку XX ст. Збірник наукових працьь, t. 28, red. О.П. Реєнт et al., Київ 2018, s. 239.
} 


\section{REFERENCES (BIBLIOGRAFIA)}

\section{Archival sources (Źródła archiwalne)}

Derzhavnyy Arkhiv Khmel'nyts'koyi Oblasti [Державний Архів Хмельницької Області]: Fond 72, opys 1, sprava 62.

Fond 73 , opys 1 , sprava 6 .

Fond 75, opys 1, sprava 24 .

Derzhavnyy Arkhiv Vinnyts'koyi Oblasti [Державний Архів Вінницької Області]:

Fond 200, opys 1, sprava 313.

Derzhavnyy Arkhiv Zhytomyrs'koyi Oblasti [Державний Архів Житомирської Області]: Fond 497, opys 1, sprava 8.

Fond 498, opys 1, sprava 71.

Tsentral'nyy Derzhavnyy Istorychnyy Arkhiv Ukrayiny m. Кууiv [Центральний Державний Історичний Архів України м. Київ]:

Fond 442 , opys 186 , sprava 271 ; opys 615 , sprava 194 ; opys 617 , sprava 170 ; opys 693 , sprava 368 ; opys 694 , sprava 34 ; opys 697 , sprava 306 ; opys 700 , sprava 56 ; opys 701 , sprava 383; opys 704, sprava 199.

\section{Printed sources (Źródła drukowane)}

Polnoye Sobraniye Zakonov Rossiyskoy Imperii, sobraniye vtoroye, t. 36, otdeleniye pervoye, 1861, Sankt Peterburg 1863. [Полное Собрание Законов Российской Империи, собрание второе, t. 36, отделение первое, 1861, Санкт Петербург 1863.]

Polnoye Sobraniye Zakonov Rossiyskoy Imperii, sobraniye vtoroye, t. 38, otdeleniye pervoye, 1863, Sankt Peterburg 1866. [Полное Собрание Законов Российской Империи, собрание второе, t. 38, отделение первое, 1863, Санкт Петербург 1866.]

Polnoye Sobraniye Zakonov Rossiyskoy Imperii, sobraniye vtoroye, t. 40, otdeleniye vtoroye, 1865, Sankt Peterburg 1867. [Полное Собрание Законов Российской Империи, собрание второе, t. 40, отделение второе, 1865, Санкт Петербург 1867.]

„Vestnik Yugo-Zapadnoy Rosii” 1863. [„Вестник Юго-Западной России” 1863.]

\section{Studies (Opracowania)}

Aksakov K., Zamechaniye na novoye administrativnoye ustroystvo krest'yan v Rossii, Leyptsig 1861. [Аксаков К., Замечание на новое административное устройство крестьян в России, Лейпциг 1861.]

Astyrev N., V volostnykh pisaryakh. Ocherki krest'yanskogo samoupravleniya, Moskva 1886. [Астырев Н., В волостных писарях. Очерки крестьянского самоуправления, Москва 1886.]

Belovinskiy L., Illyustrirovannyy entsiklopedicheskiy istoriko-bytovoy slovar' russkogo naroda, Moskva 2007. [Беловинский А., Иллюстрированный энциклопедический историко-бытовой словарь русского народа, Москва 2007.]

Bovua D., Gordiyev uzel Rossiyskoy imperii: Vlast', shlyakhta i narod na Pravoberezhnoy Ukraine (1793-1914), Moskva 2011. [Бовуа Д., Гордиев узел Российской империи: Власть, шляхта и народ на Правобережной Украине (1793-1914), Москва 2011.]

Bodnarevs'kyy A., Volosne upravlinnya ta stanovyshche selyan na Ukrayini pislya reformy 1861 roku, Kуyiv 1961. [Боднаревський А., Волосне управління та становище селян на Україні після реформи 1861 року, Київ 1961.]

Verkhovtseva I., Mizh korporatyvnistyuibyurokratyzmom: samovryaduvannya selyan u Rosiys'kiy imperiyi (druha polovyna XIX - pochatok XX st.), Cherkasy 2018. [Верховцева I., Між 
корпоративністю і бюрократизмом: самоврядування селян у Російській імперї (друга половина XIX - початок XX cm.), Черкаси 2018.]

Gorizontov L.Ye., Paradoksy imperskoy politiki: polyaki v Rossii i russkiye v Pol'she, Moskva 1999. [Горизонтов Д.Е., Парадоксы имперской политики: поляки в России и русские в Польше, Москва 1999.]

Fedorova N., Sel'skoye obshchestvo, w: Petr Arkad'yevich Stolypin: Entsiklopediya, red. V.V. Shelokhayev, Moskva 2011. [Федорова Н., Сельское общество, w: Петр Аркадьевич Стольпин: Энциклопедия, red. В.В. Шелохаев, Москва 2011.]

Hurbyk A., Chynshovi selyany, w: Entsyklopediya istoriyi Ukrayiny, t. 10, T-Ya, red. V.A. Smoliy et al., Kууіv 2013. [Гурбик А., Чиншові селяни, w: Енцзиклопедія історії Украӥни, t. 10, Т-Я, red. В.А. Смолій et al., Київ 2013.]

Kasyan A., Volosne upravlinnya Napravoberezhniy Ukrayini (1861-1917 rr.), Cherkasy 2017. [Kaсян А., Волосне управління на Правобережній Украйні (1861-1917 рр.), Черкаси 2017.]

Kryzhanivs'ka O., Vplyv reformy1861 r. na osvitu selyan Ukrayiny (druha polovyna XIX - pochatok XX st.), w: Problemy istoriyi Ukrayiny XIX - pochatku XX st. Zbirnyk naukovykh prats', t. 28, red. O.P. Reyent et al., Kууiv 2018. [Крижанівська О., Вилив реформи 1861 р. на освіту селян України (друга половина XIX - початок XX cm.), w: Проблеми історії України XIX - початку XX ст. 3бірник наукових працъь, t. 28, red. О.П. Реєнт et al., Київ 2018.]

Latyshev S., Volost', w: Entsiklopedicheskiy slovar', t. 7, Volapyuk - Vygovskiye, red. K.K. Arsen'yev, F.F. Petrushevskiy, Sankt Peterburg 1892. [Латышев С., Волость, w: Энцииклопедический словарь, t. 7, Волапюк - Выговские, red. К.К. Арсеньев, Ф.Ф. Петрушевский, Санкт Петербург 1892.]

Matsuzato K., Iz komissarov antipolonizma vprosvetiteli derevni: mirovyye posredniki na Pravoberezhnoy Ukraine (1861-1917 gg.), „Ukrayins'kyy Humanitarnyy Ohlyad” 2003, 9. [Мацузато К., Из комиссаров антиполонизма в просветители деревни: мировые посредники на Правобережной Украине (1861-1917 г2.), „Український Гуманітарний Огляд" 2003, 9.]

Meshcheryakov S., Uroven' material'nogo polozheniya chinovnikov klyuchevykh institutov upravleniya Orenburgskogo kraya vo vtoroy polovine XIX - nachale XX v., "Izvestiya Samarskogo Nauchnogo Tsentra Rossiyskoy Akademii Nauk" 2014, 16, 3, 2. [Meщеряков С., Уровень материального положения чиновников ключевых институтов управления Оренбургского края во второй половине XIX - начале XX в., „Известия Самарского Научного Центра Российской Академии Наук" 2014, 16, 3, 2.]

Ogarev N., Razbor novogo krepostnogo prava, London 1861. [Огарев Н., Разбор нового крепостного права, Пондон 1861.]

Paliyenko V., Mistsya istorychnoho rozselennya pol's'koyi lyudnosti v kintsi XIX - pochatok XX st., Kууіv 1998. [Палієнко В., Місия історичного розселення польської людності в кінці XIX - початок XX ст., Київ 1998.]

Poyda D., Krest'yanskoye dvizheniye na Pravoberezhnoy Ukraine v poreformennyy period (18661900 gg.), Dnepropetrovsk 1960. [Пойда Д., Крестьянское движение на Правобережной Украине в пореформенный период (1866-1900 г2.), Днепропетровск 1960.]

Sel'skoye obshchestvo, w: Entsiklopedicheskiy slovar', t. 29, Sakhar - Sem mudretsov, red. K.K. Arsen'yev, F.F. Petrushevskiy, Sankt Petersburg 1900. [Сельское общество, w: Эницикопедический словарь, t. 29, Сахар - Сем мудрецов, red. К.К. Арсеньев, Ф.Ф. Петрушевский, Санкт Петербург 1900.]

Ya. A., Mirovyye posredniki, w: Entsiklopedicheskiy slovar', t. 19, Mekenen-Mifu-Banya, red. K.K. Arsen'yev, F.F. Petrushevskiy, Sankt Petersburg 1896. [Я. А., Мировые посредники, w: Энияиклопедический словарь, t. 19, Мекенен-Мифу-Баня, red. К.К. Арсеньев, Ф.Ф. Петрушевский, Санкт Петербург 1896.] 
Zems'kyy Yu., Evolyutsiya pol's'ko-rosiys'kykh vzayemyn v Pravoberezhniy Ukrayini v konteksti natsionalizatsiyi svidomosti v Rosiys'kiy imperiyi seredyny XIX st., "Naukovi Zapysky Natsional'noho Universytetu „Ostroz'ka Akademiya. Seriya Istorychni nauky” 2011, 17. [Земський Ю., Еволюція польсько-російських взаємин в Правобережній Украйні в контексті націоналізациї свідомості в Російській імперії середини ХІХ ст., „Наукові Записки Національного Університету. Острозька Академія. Серія Історичні науки" 2011, 17.]

Zems'kyy Yu., Osoblyvostihenezy pol's'koho natsionalizmu v Pravoberezhniy Ukrayini seredyny XIX st., „Humanitarnyy Zhurnal” 2009, 3-4. [Земський Ю., Особливості генези польського націоналізму в Правобережній Украйні середини ХIX cm., „Гуманітарний Журнал" 2009, 3-4.]

Zems'kyy Yu., Pol's'ka, rosiys'ka ta ukrayins'ka elity v zmahannyakh za Pravoberezhnu Ukrayinu seredyny XIX stolittya, Khmel'nyts'kyу 2011. [Земський Ю., Польська, російська та українська еліти в змаганнях за Правобережну Украӥну середини ХІХ століття, Хмельницький 2011.]

\section{ABOUT THE AUTHOR}

Melnychuk Kateryna - PhD student, Department of History of Ukraine of the 19th and early 20th centuries, Institute of History of Ukraine, National Academy of Sciences of Ukraine. Scientific interests: the socio-economic history of Ukraine in the 19th and early 20th centuries. In particular, the history of the peasantry of the Ukrainian provinces that were part of the Russian Empire. History of everyday life of peasants, their economy, education and administrative management. 